I dreamt of rain: puffballs coming up along a log, a long-haired dog limping away from a mystery. Aeneas

Piccolomini, I picked you out of pine needles and the 15th century; you wondered how a pear-bush got in among the evergreen, why you came

to Scotland in the first place.

What sounds my pipes made when you danced around the pears that were ripe and in the shape of geese.

When they fell off from the fury of your ecstasy, they saw a dog wander back to its sheep, and flew away.

\title{
WHAT ARE BIRDS WORTH
}

$$
\text { for L.D. }
$$

Be a sea gull. Drop upon the beach.

Be a legal tablet or a peach come to rest upon the nose or feet of our local Hammurabies.

Birdies, beat the plums from our formal orchards, sing through the membrane of what holds us back: what's behind

the banister? A barrister? A courtly blister itching for a pin? Will it open? $\mathrm{O}$, when the saps from the phloem and the xylem and the birds (what words birds are) drop upon the beach. 